\title{
農作物中のピペロニルブトキサイドの分析について
}

\author{
(昭和 50 年 11 月 21 日受理)
}

一色賢 司 ${ }^{1 *}$ 渡 辺忠 雄*2

\section{An Analytical Method of Piperonyl Butoxide in Agricultural Products}

\author{
Kenji IsshikI*1 and Tadao WATANABE*2 \\ (*1The Kitakyushu Municipal Institute of Environmental Health Sciences: 2-1, Shin'ike-1, \\ Tobata-ku, Kitakyushu. *2Department of Food Science \& Technology, Faculty \\ of Agriculture, Kyushu University: Hakozaki, Higashi-ku, Fukuoka)
}

The clean-up methods and the gas-liquid chromatography for piperonyl butoxide (PB) were investigated to establish the analytical method of PB in agricultural products.

PB extracted with chloroform from sample was eluted from a Florisil column with a mixture of $n$-hexane, acetone and ethyl ether $(3: 1: 1)$, and from a silica gel column with a mixture of benzene and chloroform $(4: 1)$, subsequently.

The detection and determination of $\mathrm{PB}$ were carried out with gas-liquid chromatograph equipped with a flameionization detector using silicone OV-1 or SE-30 column.

PB added to cereals and beans was recovered in the range from 80.5 to $101 \%$.

(Received November 21, 1975)

食品添加物として指定されているピペロニルブトキサ イド (PB) は，ピレトリンなどの 殺虫剤の共力剤であ $\eta^{1)}$, 款類に $0.024 \mathrm{~g} / \mathrm{kg}$ 以下の使用が認められている.

また, PB は薬物代謝の阻害剤であり, 生化学的な研究 も行われている2)

農作物中の PB の分析については，比色定量を行う

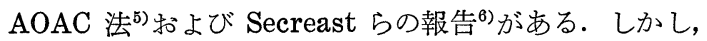
これらの比色法では PB 以外の化合物も発色する可能性 があり，操作が繁雑である。 また，農薬製剈中の $\mathrm{PB}$ の分析については，ガスクロマトグラフィーを用いた分 析法が報告されているが7),8)，農作物中には妨害物質が 多く, PB の残留分析法として利用することは困難であ った.

本実験において, 農作物中の PB の残留量を知るため に，クリーンアップ拉よびガスクロマトグラフィーの条 件などについて検討を行い若干の知見を得たので報告す る.

\section{実験方法}

\section{1. 試料}

北九州市内で販売されていた玄米，白米，ぬか，小

*1 北九州市環境衛生研究所：北九州市戸烟区 新池 12-1

*2 九州大学農学部食糧化学工学科：福岡市東区箱崎
麦, 大麦，そば，とうもろこし，大豆，小豆を購入して 5 ○保存した.

\section{2. 試薬}

ピペロニルブトキサイド：ガスクロ工業製残留農薬分 析用標準品.

n-ヘキサン，クロロホルム，ベンゼン，アセトン：市 販の一級品をガラス製蒸留装置で蒸留した. 初留 $10 \%$, 後留 $20 \%$ をットし，ガスクロマトグラム上に妨害ピー クを与えないことを確認して用いた.

エチルエーテル：林純薬製残留農薬分析用.

酢酸エチル：和光純薬製特級品.

ピレン：東京化成製一級品.

リン酸: 和光純薬製特級品.

酢酸：和光純薬製特級品.

タンニン酸：キシダ化学製.

フロリジル：Floridin Co. 製フロリジル（60１00メ

ッシュ). $130^{\circ}$ で15時間加熱活性化して用いた.

シリカゲル：和光純薬製ワコーゲル（100 200メッシ

ュ). $130^{\circ}$ で15時間加熱活性化して用いた。

無水硫酸ナトリウム：和光純薬製特級品を，600で 2 時間加熱して用いた.

シリカゲル薄層板：ヤマト科学製 Replate-50 (50× $200 \mathrm{~mm})$. 
Table 1. Condition of Gas Chromatography

\begin{tabular}{|c|c|c|c|}
\hline & & $2 \%$ OV -1 & $5 \%$ SE-30 \\
\hline \multicolumn{2}{|l|}{ Model } & \multicolumn{2}{|c|}{ Shimadzu GC-3BF } \\
\hline Column & $\begin{array}{l}\text { Inner diameter }(\mathrm{mm}) \\
\text { Length }(\mathrm{m})\end{array}$ & $\begin{array}{l}3 \\
2.1\end{array}$ & $\begin{array}{l}3 \\
1.2\end{array}$ \\
\hline Support & $\begin{array}{l}\text { Mesh } \\
\text { Treatment }\end{array}$ & $\begin{array}{c}\text { Gas Chrom Q } \\
60 / 80 \\
\text { AW. DMCS. }\end{array}$ & $\begin{array}{c}\text { Chromosorb } \\
80 / 100 \\
\text { AW. DMCS. }\end{array}$ \\
\hline Carrier gas, & Flow fate $(\mathrm{ml} / \mathrm{min})$ & \multicolumn{2}{|c|}{$\begin{array}{l}\text { Nitrogen } \\
\quad 60\end{array}$} \\
\hline Detector & & \multicolumn{2}{|c|}{ FID } \\
\hline Temperature & $\begin{array}{l}\text { Column (C) } \\
\text { Injection (C) }\end{array}$ & \multicolumn{2}{|c|}{250} \\
\hline
\end{tabular}

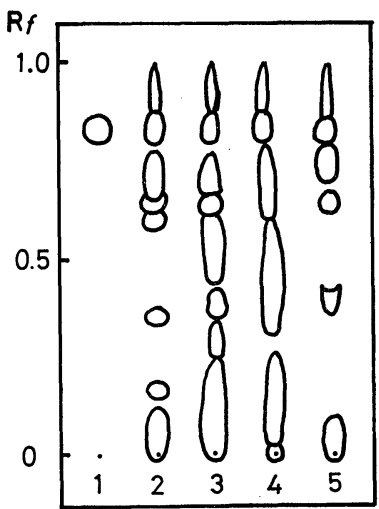

Fig. 1. Thin-layer chromatograms of standard $\mathrm{PB}$ and $\mathrm{PB}$ added samples

1: $\mathrm{PB}, 2$ : hulled rice, 3: unhulled rice, 4: corn, 5: wheat.

\section{3. 装置}

ガスクロマトグラフ：島津製 GC-3BF（検出器 FID）

粉砕機：吉田製作所製ウィリー1029A型

振とう機：イワキ製 V-S 型 ロータリーエバポレーター: 柴田化学工業製, SPC 型 電気定温器：池本理化工業製1201型

\section{4. 実験操作}

\section{1. 簿層クロマトグラフィー}

薄層板としてシリカゲルの厚さ $0.2 \mathrm{~mm}$ の Replate50 を用いた以外は, Olive の方法" ${ }^{9}$ に従って操作を行っ た. 展開溶媒は，ベンゼン一眽酸エチル混液 $(85: 15$, $\mathrm{v} / \mathrm{v})$ とし，展開距離は $10 \mathrm{~cm}$ とした。発色剂は， $1 \mathrm{ml}$ の0.33\%タンニン酸を含む酢酸, $3 \mathrm{ml}$ の $85 \%$ リン酸 おo
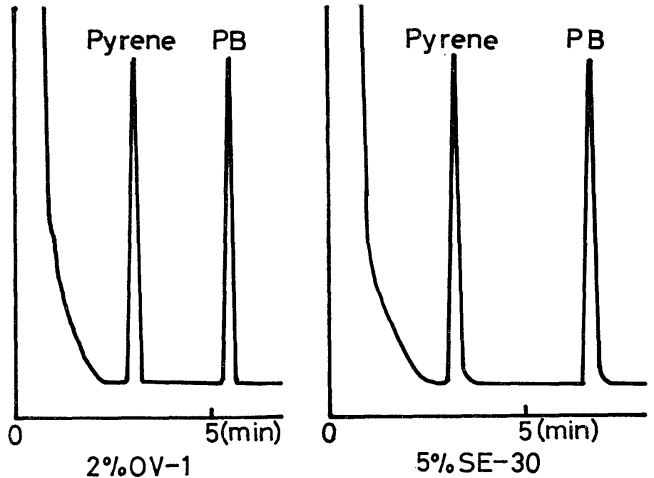

Fig. 2. Gas chromatograms of $\mathrm{PB}$ and pyrene as an internal standard

よび $26 \mathrm{ml}$ のアセトンを使用直前に 混合したものを用 いた。展開後, 薄層板を乾燥させ, 発色剂を噴霧して電 気定温器中で $90^{\circ}$ に 15 分間保ち発色させた.

\section{2. ガスクロマトグラフィー}

定量は $2 \%$ シリコンOV-1 カラムと $5 \%$ \%リコン SE30 カラムを取り付けたガスクロマトグラフを用いて行 い，その操作条件は Table 1 に示した. 内部標準溶液

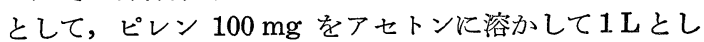
たものを用いた。試験溶液に内部標準溶液 $1 \mathrm{ml}$ お。よび アセトンを加えて $5 \mathrm{ml}$ とし，ガスクロマトグラフィー を行い，PB とピレンの面積比によって定量を行った。

\section{3. フロリジルカラムクロマトグラフィー}

内径 $2 \mathrm{~cm}$, 長さ $30 \mathrm{~cm}$ のクロマト管にまず無水硫酸 ナトリウム $5 \mathrm{~g}$, フロリジル $20 \mathrm{~g}$, 無水硫酸ナトリウム $5 \mathrm{~g}$ の順に $n$-ヘキサンを用いた湿式法で充てんした。こ のカラムに試料を注入し，まず $n$-ヘキサンーエチルエー 
Table 2. Recovery of PB by Florisil Column

\begin{tabular}{c|c|c|c|c}
\multirow{2}{*}{ Solvent system } & \multirow{3}{|c}{ Recovery (\%) } \\
\cline { 3 - 5 } & Elution volume (ml) & \multicolumn{3}{|c}{ Added PB (mg) } \\
\cline { 3 - 5 } & & 0.01 & 0.1 & 0 \\
\cline { 3 - 5 } & $50 \sim 100$ & 0 & 0 & 0 \\
\hline A & $100 \sim 150$ & 99.0 & 98.5 & 1.6 \\
& $150 \sim 200$ & trace & 0.8 & 0
\end{tabular}

A, mixture of $n$-hexane and ethyl ether $(1: 1, \mathrm{v} / \mathrm{v}) ; \mathrm{B}$, mixture of $n$-hexane, acetone and ethyl ether $(3: 1: 1, \mathrm{v} / \mathrm{v})$

Table 3. Recovery of PB by Silica Gel Column

\begin{tabular}{c|c|c|c|c}
\multirow{2}{*}{ Solvent system } & \multirow{3}{*}{ Elution volume (ml) } & \multicolumn{3}{|c}{ Recovery (\%) } \\
\cline { 3 - 5 } & & 0.01 & 0.1 & 1 \\
\cline { 2 - 5 } & $0 \sim 50$ & 0 & 0 & 0 \\
\hline A & $50 \sim 100$ & 0 & 0 & trace PB (mg) \\
& $100 \sim 150$ & trace & 99.6 & 99.9 \\
& $150 \sim 200$ & 98.4 & 0 & 0
\end{tabular}

A, benzene; B, mixture of benzene and chloroform $(4: 1, \mathrm{v} / \mathrm{v})$

テル混液 $(1: 1, \mathrm{v} / \mathrm{v}) 100 \mathrm{ml}$ ，ついで $n$-ヘキサンーア セトンーエチルエーテル混液 $(3: 1: 1, \mathrm{v} / \mathrm{v}) 150 \mathrm{ml}$ を 用いて溶出した．溶出速度は $1 \mathrm{ml} / \mathrm{min}$ とした．溶出液 はクデルナ・ダニッシュ $(\mathrm{KD})$ 濃縮器で $5 \mathrm{ml}$ 以下に濃 縮した.

\section{4. シリカゲルカラムクロマトグラフィー}

内径 $1 \mathrm{~cm}$, 長さ $30 \mathrm{~cm}$ のクロマト管にまず無水硫酸ナ トリウム $1 \mathrm{~g}$, シリカゲル $3 \mathrm{~g}$, 無水硫酸ナトリウム $1 \mathrm{~g}$ の順にベンゼンを用いた湿式法で充てんした.このカラ ムに，試料を注入し，まずベンゼン $100 \mathrm{ml}$ ，ついでベン ゼンークロロホルム混液 $(4: 1, \mathrm{v} / \mathrm{v}) 150 \mathrm{ml}$ を用いて溶 出した。溶出速度は $1 \mathrm{ml} / \mathrm{min}$ とした. 溶出液は $\mathrm{KD}$ 濃 縮器で濃縮した後, 空気を吹き付けて残った溶媒を揮散 させた。

\section{5. 試験溶液の調製}

粉研機を用いて粉研し均質化した試料 $25 \mathrm{~g}$ 亿， 0.01 , 0.1 および $1 \mathrm{mg}$ の $\mathrm{PB}$ を添加した後, $300 \mathrm{ml}$ の分液 漏斗に入れ，クロロホルム $200 \mathrm{ml}$ を加えて垂直型振と う機で 1 時間激し々振とう抽出した. 抽出後, ガラス漏 斗 G-3 または G-4を用いて吸引ろ過し，残留物をク口 ロホルム $200 \mathrm{ml}$ でよく洗浄した. 万液を無水硫酸ナト
リウムで脱水した後ロータリーエバポレーターを用い て濃縮した．この濃縮液を, 薄層クロマトグラフィ一用 検液とした。また，濃縮液をへキサンで $5 \mathrm{ml}$ とし，フ ロリジルカラムクロマトグラフィー，ついでシリカゲル カラムクロマトグラフィーにより精製し, ガスクロマト グラフィー用検液とした.

\section{実験結果}

1. 簿層クロマトグラフィー

PB は， $R f=0.82$ 亿青色のスポットとして検出され， 最少検出量は $1 \mu \mathrm{g}$ であった. Fig. 1, に, 白米, 玄米, とうもろこしおよび小麦に $40 \mathrm{ppm}$ の $\mathrm{PB}$ を添加した 時の結果を示した.

\section{2. ガスクロマトグラフィー}

Fig. 2 に PB の OV-1 特よび SE-30 カラムを用い たガスクロマトグラムを示した. 内部標準物質のピレン に対する PB の相対保持時間は, OV-1 で1.78, SE-30 では2.06であった. SE-30では，ピークがややテーリン グを示した。両カラムとも Table 1 に示す条件下で $0.005 \mu \mathrm{g}$ の $\mathrm{PB}$ をフルスケールの $3 \%$ として検出が可 能であった. 
Table 4. Average Recovery of PB Added to Some Agricultural Products

\begin{tabular}{|c|c|c|c|c|}
\hline \multirow{3}{*}{ Sample } & \multirow{3}{*}{$\begin{array}{c}\text { No. of } \\
\text { Samples }\end{array}$} & \multicolumn{3}{|c|}{ Recovery $(\%)$} \\
\hline & & \multicolumn{3}{|c|}{ Added PB (mg/25 g sample) } \\
\hline & & 0.01 & 0.1 & 1 \\
\hline Unhulled rice & 4 & $93.2 \pm 4.3$ & $86.3 \pm 1.8$ & $100 \pm 3.7$ \\
\hline Hulled rice & 6 & $96.3 \pm 9.5$ & $98.4 \pm 4.3$ & $94.0 \pm 7.0$ \\
\hline Rice bran & 4 & $84.3 \pm 5.3$ & $87.5 \pm 9.6$ & $93.5 \pm 4.1$ \\
\hline Wheat & 3 & $97.8 \pm 4.1$ & $101 \pm 9.3$ & $95.5 \pm 7.9$ \\
\hline Barley & 3 & $98.4 \pm 6.6$ & $94.0 \pm 5.7$ & $85.4 \pm 5.5$ \\
\hline Buck wheat & 3 & $93.7 \pm 7.5$ & $87.0 \pm 7.4$ & $90.6 \pm 8.8$ \\
\hline Corn & 3 & $88.4 \pm 3.0$ & $95.0 \pm 4.5$ & $87.6 \pm 9.7$ \\
\hline Soy bean & 4 & $93.1 \pm 7.1$ & $80.5 \pm 3.2$ & $84.8 \pm 5.7$ \\
\hline Red bean & 3 & $87.0 \pm 7.9$ & $90.4 \pm 7.1$ & $88.7 \pm 2.5$ \\
\hline
\end{tabular}

Figures indicate average \pm S. D.

\section{3. クリーンアップ}

試料中の PB をクリーンアップするために，まずフロ ジルカラムクロマトグラフィーの検討を行った．PB は フロリジルカラムに执いて，Table 2 のようにn一へキ ンーエチルェーテル混液 (1:1, v/v) $100 \mathrm{ml}$ では溶出さ れず， $n$-ヘキサンーアセトンーェチルェーテル混液 (3 : $1: 1, \mathrm{v} / \mathrm{v})$ で溶出された. しかし, 試料中の妨害物質 は，フロリジルカラムによるクリーンアップだけでは除 去することができなかった，溶出溶媒として，ベンゼン やクロロホルムを用いた場合は, PB のテーリングがあ り，また妨害物質の除去もできなかった，そのため，シ リカゲルカラムクロマトグラフィーを続いて検討した。

PB はシリカゲルカラムに捻いて, Table 3 のようにベ ンゼン $100 \mathrm{ml}$ では溶出されず, ベンゼンークロロホル ム混液 $(4: 1, \mathrm{v} / \mathrm{v}) 150 \mathrm{ml}$ で溶出された。

このフロリジルカラムとシリカゲルカラムを用いるク リーンアップによって試料中の妨害物質を除くことがで きた。な拉，呚や大豆などの抽出物は，クリーンアッ プ後も PB 分画着色がみられたが，ガスクロマトグラ ム上には妨害ピークとして現れなかった。

\section{4. 添加回収実験}

穀類および豆類に PB を添加して上述の実験操作に従 いその回収率を求めると, Table 4 に示すように, 80.5 101\%の範囲内にあった. Table 4 は各試料につき 3 回 ずつ添加回収実験を行った結果である.

\section{考察}

農作物中に残留する PB の分析法について検討を行っ た結果，フロリジルカラム执よびシリカゲルカラムによ るクリーンアップを行った後, ガスクロマトグラフィー による定性打よび定量分析が可能になった.クリーンア ップ操作として，活性炭カラムクロマトグラフィーおよ びアセトニトリルーn-ヘキサン分配についても検討を行 った. しかし， PBは活性炭カラムから $n$-ヘキサンーエ
チルエーテル混液 $(3: 1, \mathrm{v} / \mathrm{v})$ で回収されたが，ガスク ロマトグラム上に妨害物質が多く，さらにフロリジルカ ラムおよびシリカゲルカラムによるクリーンアップが必 要であった．また，アセトニトリル一シ்-ヘキサン分配に おいても，PB はアセトニトリル層に移行していたが， 活性炭カラムの場合と同様に，フロリジルカラムおよび シリカゲルカラムによるクリーンアップが必要であっ た. したがって，ここではフロリジルカラムとシリカゲ ルカラムによるクリーンアップを採用した. PB はフロ リジルカラムやシリカゲルに対して吸着力が強いため, まず極性の低い溶媒により妨害物質を除去し，ついで極 性のより高い溶媒で収率よく回収することができた。し かし, 極性の高い試料に共存している色素などが PB 分 画に溶出する場合があった，特にぬかや大豆では，PB 分画に着色がみられたが，ガスクロマトグラム上では内 部標準物質および PB のピークと重ならず，定性または 定量に影響を及ぼさなかった。

AOAC 法6 ${ }^{6}$ および Secreast らの方法7)では，濃縮を すべて空気の吹き付けによって行っているが，本実験で はロータリーエバポレーターとKD 濃縮器を用いた.こ れらの濃縮器の使用による PB の回収率の低下は見られ ず，濃縮時間も短縮された。

PB のガスクロマトグラフィーによる分析に执いてこ れまでに, $3 \sim 5 \% \mathrm{SE}-30^{7)}, 5 \% \mathrm{OV}-1^{8)}, 5 \% \mathrm{OV}-17^{10)}$, 10\% OV-225 ${ }^{11)}$ 扎よび 10\% Apiezon $\mathrm{L}^{12)}$ などのカラ ムが報告されている. 本実験に当たり，5\% DC-11， 1 5\% OV-1, 2\% OV-11, 1 5\% OV-17, 2 5\% SE30，4\% SF-96 および 3\% XE-60 などのカラムにつ いて検討したところ，2\% OV-1 が最も良好であった。 このことについては，米国食品薬品局の Schepman に よっても同様の結果が得られている*. また, $5 \% \mathrm{SE}-30$ も使用したが， $2 \%$ OV-1 とともに $0.005 \mu \mathrm{g}$ までの PB

* Schepman, J. B.: 私信 
が検出可能であった。食品衛生法で現在許可されている $\mathrm{PB}$ の使用量は, 穀類 $1 \mathrm{~kg}$ 当たり $0.024 \mathrm{~g}$ 以下である ので，今回報告した方法は十分に残留分析法として使用 でさると思われる．また，Olive の方法"9ににたがって 行った薄層クロマトグラフィーは， $1 \mu \mathrm{g}$ の PB を検出 し得たので，ガスクロマトグラフを用いなくても PB の 定性分析法として適用できると思われる。

我々は現在食品や環境中に残留していると思われる PB について検討中である.

\section{要 約}

農作物中の PB の分析法について検討し，次のような 結果を得た。

1） PB はフロリジルおよびシリカゲルカラムクロマ トグラフィーにより他の妨害物質からクリーンアップさ れた。

2) $\mathrm{PB}$ のガスクロマトグラフィーの諸条件について 検討し， $2 \%$ OV-1 および $5 \%$ SE-30 カラムにより定 量が可能であった.

3) 数種の穀類および豆類について, PB の添加回収 実験を行い，80.5〜101\%の回収率を得た。

終りに臨み, 終始御助言御援助をいただいた北九州市 環境衛生研究所長, 秋山 高博士はじめ職員の皆様に深 く感謝いたします。

文献

1) Casida, J. E.: J. Agric. Food Chem., 18, 753 (1970).
2) Friedman, M. A., Greene, E.J., Csillag, R., Epstein, S. S.: Toxicol. Appl. Pharmcol., 21, 419 (1972).

3) Philpot, R. M., Hodgson, E.: Mol. Pharmacol., 8, 204 (1972).

4) Solomon, K.R., Bowlus, S. B., Metcalf, R. L., Katzenellenbogen, J.A.: Life Sci., 13, 733 (1973).

5) The Association of Official Analytical Chemists: "Method of Assoc. Offic. Anal. Chem., 12th ed." p. 551 (1975).

6) Secreast, M.F., Cail, R.S.: J. Agric. Food Chem., 19, 192 (1971).

7) Bevenue, A., Kawano, Y., DeLano, F.: J. Chromatog., 50, 49 (1971).

8) Meinen, V.J.: J. Assoc. Offic. Anal. Chem., 58, 854 (1975).

9) Olive, B. M.: ibid., 56, 915 (1973).

10) McLeod. H. A., Butterfield, A. G., Lewis, A., Phillips, W. E. J., Coffin, D. E.: Anal. Chem., 47, 674 (1975).

11) Albro, P. W., Fishbein, L., Fawkes, J.: J. Chromatog., 65, 521 (1972).

12) Miller, W. K., Twett, O.: J. Agric. Food Chem., 15, 931 (1967). 